\title{
Length-weight relationship and relative condition factor of five Labeo spp. from river Cauvery in India
}

\author{
S. SIBINA MOL ${ }^{1}$, A. K. JAISWAR ${ }^{2}$, P. PANIKKAR ${ }^{1}$, B. K. BEHERA ${ }^{3}$, H. SANATH KUMAR ${ }^{2}$, \\ C. M. ROSHITH ${ }^{3}$, M. E. VIJAYKUMAR ${ }^{1}$, S. K. SHARMA ${ }^{3}$, R. K. MANNA ${ }^{3}$ AND B. K. DAS ${ }^{3}$ \\ ${ }^{1}$ Bangalore Research Centre of ICAR-Central Inland Fisheries Research Institute, Bangalore - 560089 \\ Karnataka, India \\ ${ }^{2} I C A R-C e n t r a l$ Institute of Fisheries Education, Versova, Mumbai - 400 061, Maharashtra, India \\ ${ }^{3}$ ICAR-Central Inland Fisheries Research Institute, Barrackpore, Kolkata - 700 120, West Bengal, India \\ e-mail: basantakumard@gmail.com
}

\begin{abstract}
Length-weight relationship (LWR) of five species of the genus Labeo (Family: Cyprinidae) namely L. rohita (Hamilton, 1822), L. calbasu (Hamilton,1822), L. bata (Hamilton,1822), L. dyocheilus (McClelland, 1839) and L. porcellus (Heckel, 1844), based on 214 specimens collected from Cauvery River in Peninsular India, were established. Sampling was carried out from December 2017 to December 2018 at around three months interval. The value of regression coefficient (b) ranged from 2.6147 (L. bata) to 3.2855 (L. dyocheilus). A new maximum length of $41 \mathrm{~cm}$ for L. porcellus has been recorded. For L. porcellus, LWR is established for the first time while for other species (except L. rohita); it is estimated for the first time from a peninsular river in India. Relative condition factor estimated for the five fish species did not show large scale variation (1.001 to 1.019$)$
\end{abstract}

Keywords: Cauvery, Condition factor, Labeo, Length-weight relationship

Length of a particular species is uniquely correlated with its weight. Length-weight relationship (LWR) studies help in biometric and morphological comparisons of different fish species from the same taxonomic group (Baeck et al., 2012), as well as in fish stock assessments (Borah et al., 2017). This can also be utilised in studying populations of a particular species at different locations. Relative condition factor refers to variation of observed weight from that of the expected weight and can be used as an indicator of the well-being of fishes (Le Cren, 1951). It may be influenced by geographical, seasonal and biological variations (Froese, 2006). Thus, sampling location, sampling season and gear influence the values.

Cauvery is the third largest river in peninsular India, flowing mainly through the states of Karnataka and Tamil Nadu. It has its origin in Tala Cauvery (Bhrahmagiri Hills) at $1355 \mathrm{msl}$ in Kodagu District, Karnataka. It traverses $800 \mathrm{~km}$, draining an area of $89600 \mathrm{~km}^{2}$ to join Bay of Bengal (BoB) at Kaveripattinam in Tamil Nadu (Singh et al., 2003). The river course is divided into mountainous (origin to Sivanasamudram), plateau (Sivanasamudram to Hogenakkal) and plain zone (Hogenakkal to confluence in BoB). Labeo spp. contributes considerably to the commercial catches from the river, especially in freshwater mountainous and plateau zones (Singh et al., 2003). LWRs of five species of the genus Labeo (family: Cyprinidae) namely L. rohita (Hamilton 1822), L. calbasu (Hamilton 1822), L. bata (Hamilton 1822), L. dyocheilus (McClelland 1839) and L. porcellus (Heckel 1944) recorded from Cauvery was established. There are no previous records of LWR of above mentioned species, except $L$. rohita, from the peninsular rivers in FishBase (Froese and Pauly, 2018). Further, record of LWR of L. porcellus, from any region is not available in FishBase, the global database for fish species (www.fishbase.org).

Samples for the present study were collected at Valnoor $\left(12^{\circ} 20^{\prime} 28.50^{\prime \prime N}\right.$; 7553'29.87’'E), Kudige (12³0’35.16”N; 75 57'52.15”E), T. Narasipura (12¹3'9.04”N; 7654'37.58”'E), Sivanasamudra (12 $15^{\prime} 0.98^{\prime \prime} \mathrm{N}$; 7 $7^{\circ} 9^{\prime} 10.56$ 'E) and Hogenakkal (126'56.29”N; 7746’36.86”E) along River Cauvery. Sampling was carried out from December 2017 to December 2018 at around three months interval. Fresh specimens (Labeo spp.), caught using cast net and gillnet of mesh size ranging from $20-220 \mathrm{~mm}$, were identified following Jayaram (1999). The total length and weight of 214 specimens, without any deformities, were measured to the nearest millimetre and weighed to the nearest $0.1 \mathrm{~g}$. LWR was established using the standard cube law (Froese, 2006) given as:

$$
\mathrm{W}=\mathrm{aL}^{\mathrm{b}}
$$


where, $\mathrm{W}$ and $\mathrm{L}$ are weight $(\mathrm{g})$ and length $(\mathrm{cm})$ of the fish, and $a$ and $b$ are the regression and allometric constants, respectively.

Length and weight of the specimens were log transformed; then following the logarithmic transformation of the cube law $(\log W=\log a+b \log L)$, the LWR of each species of fish was determined in order to establish a linear relationship. Using Froese (2006), outliers were trimmed off.

Thereafter, using the formula $\mathrm{K}_{\mathrm{n}}=\mathrm{W} / \mathrm{W}$, (W being the weight of the fish under consideration and $\hat{W}$ the estimated weight derived from the established lengthweight relationship) (Le Cren, 1951), the relative condition factor was estimated for each species.

The sample size, descriptive statistics and estimated length-weight parameters for the five species are given in Table 1. Growth of fish was considered to be isometric when ' $b$ ' is equal to 3 . The growth was positively allometric
Tamil Nadu (Natarajan, 1971), Loni Reservoir in Madhya Pradesh (Pathak, 1975) and Kali River in Uttar Pradesh (Chatterji et al., 1980), respectively, showing an isometric or a positive allometric growth pattern. The length-weight relationship studies on $L$. bata reported ' $b$ ' value of 3.16 and 3.02 from river Kali in Uttar Pradesh (Chatterji et al., 1977) and river Ganga (Khan, 2012), respectively. The study on the species from Kulia Beel in West Bengal (Sarkar et al., 2017) estimated ' $b$ ' value of 2.9 showing a negative allometry in the growth pattern of the species similar to the results of the present study. Das et al. (2015) estimated ' $b$ ' value of 3.06 for males and 2.89 for females from Deepor Beel in Assam. In case of L. rohita, Sarkar et al. (2017) from Kulia Beel, West Bengal and Ujjania et al. (2013) from Mahi Bajaj Sagar Reservoir, Rajasthan, reported ' $b$ ' value of 2.89 and 2.97 respectively, revealing similar negative allometric growth as in the present study from Cauvery River.

Table 1. Descriptive statistics and estimated length-weight parameters for five Labeo spp. from Cauvery River in Peninsular India

\begin{tabular}{|c|c|c|c|c|c|c|c|c|c|c|}
\hline \multirow{2}{*}{ Species } & \multirow{2}{*}{$\mathrm{n}$} & \multicolumn{2}{|c|}{ Total length $(\mathrm{cm})$} & \multicolumn{2}{|c|}{ Total weight (g) } & \multicolumn{4}{|c|}{ Regression parameters } & \multirow[b]{2}{*}{$\mathrm{R}^{2}$} \\
\hline & & Min. & Max. & Min. & Max. & $a^{\prime}$ & $95 \% \mathrm{CI}$ of a & $\mathrm{b}$ & $95 \% \mathrm{CI}$ of $\mathrm{b}$ & \\
\hline L. calbasu & 74 & 8.4 & 55 & 9.1 & 1503.5 & 0.0086 & $0.0057-0.0129$ & $3.0693^{*}$ & $2.9489-3.1898$ & 0.97 \\
\hline L. bata & 31 & 13.9 & 17.2 & 24 & 43.4 & 0.0254 & $0.0088-0.0734$ & $2.6147^{*}$ & $2.2268-3.0026$ & 0.87 \\
\hline L. rohita & 66 & 16 & 50 & 50.3 & 1600 & 0.0164 & $0.0093-0.0286$ & $2.9087^{*}$ & $2.7449-3.0724$ & 0.95 \\
\hline L. dyocheilus & 23 & 11.0 & 44.3 & 10.5 & 950 & 0.0039 & $0.0028-0.0054$ & $3.2855^{*}$ & $3.1803-3.3907$ & 0.99 \\
\hline L. porcellus & 20 & 34.7 & $41^{\ddagger}$ & 403.4 & 655.3 & 0.0379 & $0.0017-0.8559$ & $2.628^{*}$ & $1.7699-3.4861$ & 0.70 \\
\hline
\end{tabular}

n-Sample size; $\mathrm{Cl}$ - Confidence limits; $\mathrm{a}$ and $\mathrm{b}$ - Parameters; $\mathrm{R}^{2}$ - Coefficient of determination

'Antilog (intercept); ${ }^{*}$ significant at $\mathrm{p}<0.01$; ${ }^{*}$ New maximum length recorded

when $b>3$ and negatively allometric when $b<3$ (Dutta et al., 2012). The standard range of ' $b$ ' value for finfish was suggested between 2.5 and 3.5 (Froese, 2006). In present study, estimated values of ' $a$ ' and ' $b$ ' are well within the expected range and significant at $1 \%$ level of significance $(\mathrm{p} \leq 0.01)$. The ' $b$ ' value of the Labeo spp. studied varied from 2.6147 (L. bata) to 3.2855 (L. dyocheilus). The ' $b$ ' value of L. bata (2.6147) and L. porcellus (2.628), showed a negative allometry in growth i.e., the fish tends to become slender as it grows. The ' $b$ ' values of $L$. calbasu (3.0693) and $L$. rohita (2.9087) revealed an isometric growth. L. dyocheilus (3.2855) with ' $b$ ' value $>3$ exhibits positive allometric growth i.e., the fish becomes deep bodied with increase in length (Riedel et al., 2007).

The ' $b$ ' value, for a fish species, may differ with locality, sex and life stages. There may be seasonal changes, changes due to availability of food and health of ecosystem too (Le Cren, 1951). Earlier studies on lengthweight relationship of $L$. calbasu reported ' $b$ ' values of 3.11, 3.00 and 3.17 from Bhavanisagar Reservoir in
Goodness of fit of the regression model is indicated by $\mathrm{R}^{2}\left(0 \leq \mathrm{R}^{2} \leq 1\right)$, which determines the accuracy of the model. The most accurate model in the present study is that of L. dyocheilus $\left(\mathrm{R}^{2}=0.99\right)$, the sample covering length range from 11 to $44.3 \mathrm{~cm}$. In the present study, LWR for L. porcellus is described for the first time along with a new maximum length of $41 \mathrm{~cm}$ as per FishBase, where the previous maximum length recorded is $35 \mathrm{~cm}$ (Pethiyagoda, 1991). Length-weight relationship of the five species is depicted in Fig. 1(a-e).

Study on the relationship of length and weight of fish provides basic information required for fisheries resource management. LWRs can be used to convert length-frequency observations to biomass estimates while modelling an aquatic ecosystem (Kulbicki et al., 2005) and in converting length data obtained from back calculations on otoliths and scales. LWRs of other freshwater fishes from Indian rivers were previously reported by Baitha et al. (2018), Borah et al. (2018), Koushlesh et al. (2018), Baitha et al. (2017) and Nath et al. (2017). 


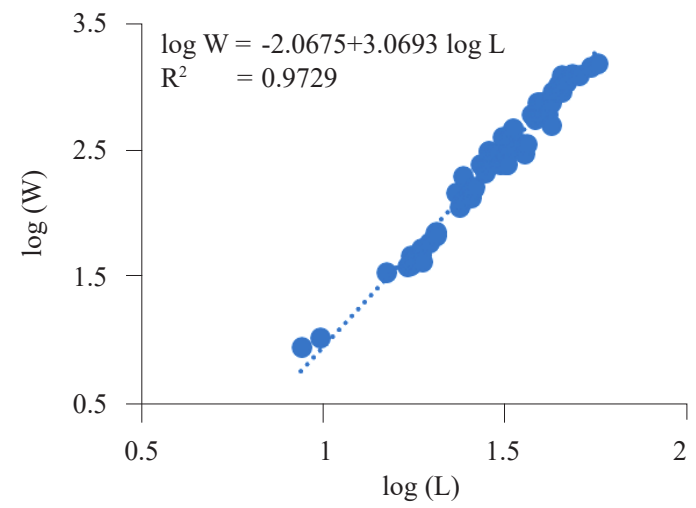

(a)

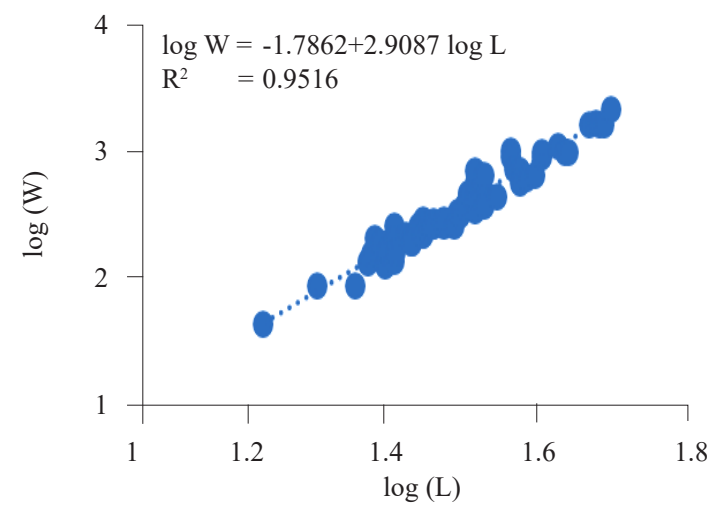

(c)

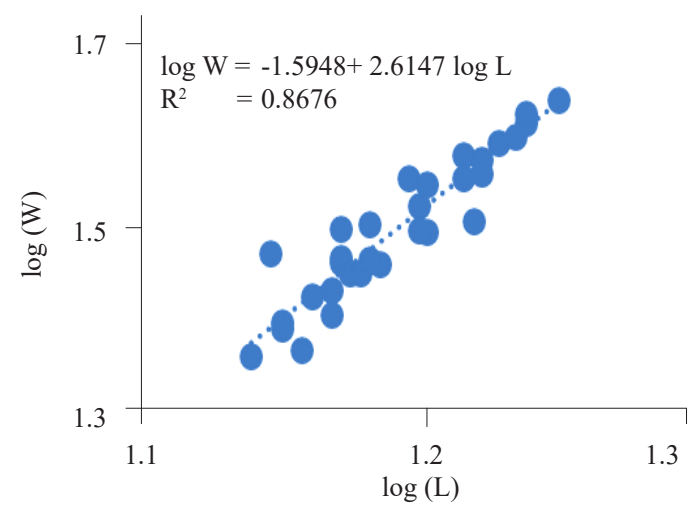

(b)

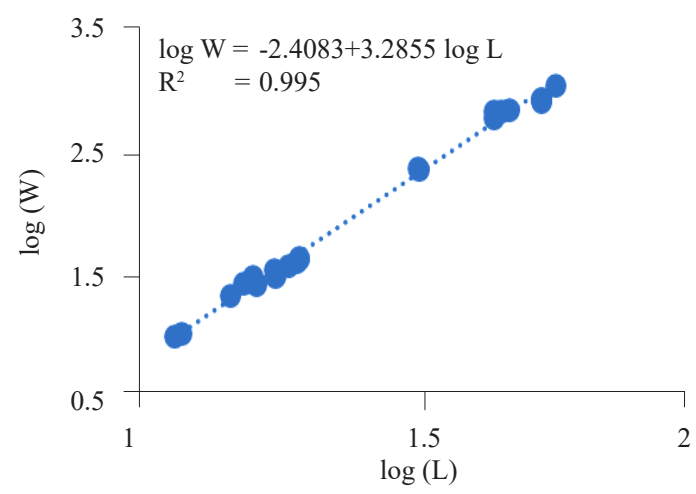

(d)

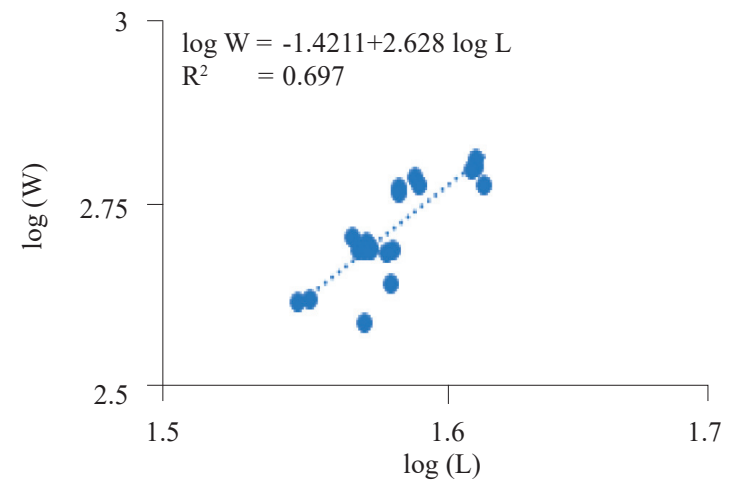

(e)

Fig.1. Length-weight relationship of (a) L. calbasu, (b) L. bata, (c) L. rohita, (d) L. dyocheilus and (e) L. porcellus

The relative condition factor for L. calbasu, L. bata, L. rohita, L. dyocheilus and L. porcellus were estimated as $1.019 \pm 0.023,1.001 \pm 0.011,1.013 \pm 0.021,1.005 \pm$ 0.023 and $1.003 \pm 0.017$, respectively (Table 2 ). Condition factors are used in the comparison of wellbeing of fish based on the assumption that heavier fish of a given length are in better condition (Froese, 2006). In the present study, estimated condition factor values above 1.00 indicates that fish of a specific length weighs more than the expected
Table 2. Relative condition factor of Labeo spp. from Cauvery River

\begin{tabular}{ll}
\hline Species & $\mathrm{Kn} \pm \mathrm{SE}$ \\
\hline L. calbasu & $1.019 \pm 0.023$ \\
L. bata & $1.001 \pm 0.011$ \\
L. rohita & $1.013 \pm 0.021$ \\
L. dyocheilus & $1.005 \pm 0.023$ \\
L. porcellus & $1.003 \pm 0.017$ \\
\hline
\end{tabular}

$\mathrm{Kn}$ - Relative condition factor; SE - Standard error of the sample 
weight and this indicates Cauvery River is a conducive environment for all the five species.

Authentic information on LWRs and Kn is inevitable for biologists in conserving ichthyofauna. LWRs may be utilised in comparing the health of a species in time and space and predict the health of the concerned ecosystem. Results of this study may serve as baseline data for fish population studies, stock delineation and assessment, and in formulation of suitable practices for sustainable management of fishery resources.

\section{Acknowledgements}

The data for the present study were collected during the sampling visits under the institute research project "Habitat characterisation, fisheries and socio-economics of rivers Cauvery, Tapti, Siang and Chaliyar" (REF/1720/07) of ICAR-CIFRI. The authors extend sincere thanks to S. Koushlesh and S. Borah for their help during the study and the fisher community of Cauvery River for their cooperation during sample collection.

\section{Reference}

Baeck, G. W., Jeong, J. M., Yeo, Y. M., Huh, S. H. and Park, J. M. 2012. Length-weight and length-length relationships for 10 species of scorpion fishes (Scorpaenidae) on the south coast of Korea. J. Appl. Ichthyol., 28(4): 677-679. http://dx.doi.org/10.1111/j.1439-0426.2012.01956.x.

Baitha, R., Karna, S. K. and Ray, A. 2018. Length-weight and length-length relationships of eight fish species from river Ganga, India. J. Appl. Ichthyol., 34: 1052-1054. https://doi. org/10.1111/jai.13698.

Baitha, R., Sinha, A. and Koushlesh, S. K.2017. Length-weight relationship of ten indigenous freshwater fish species from Gandak River, Bihar, India. J. Appl. Ichthyol., 34: 233-236. https://doi.org/10.1111/jai.13555.

Borah, S., Bhattacharjya, B. K. and Saud, B. J. 2017. Lengthweight relationship of six indigenous fish species from Deepor Beel, a Ramsar site in Assam, India. J. Appl. Ichthyol., 33: 655-657. https://doi.org/10.1111/jai.13348.

Borah, S., Gogoi, P. and Bhattacharjya, B. K. 2018. Lengthweight and length-length relationship of two endemic snakehead fish species from Brahmaputra River basin, Assam, India. J. Appl. Ichthyol., 34: 788-790. https://doi. org/10.1111/jai.13685.

Chatterji, A., Siddiqui, A. Q. and Khan, A. A. 1977. Lengthweight relationship of carp, Labeo bata (Ham.). Proc. Indian Acad. Sci., 86B(3): 189-194.

Chatterji, A., Ali, M. and Mumtaz, A. 1980. A note on the length weight relationship of kalbasu, Labeo calbasu (Ham.). Indian J. Fish., 27(1-2): 261-263.

Das, G., Chakravorty, H. and Deka, P. 2015. Length-weight relationship and relative condition factor of Labeo bata
(Hamilton, 1822) from Deepor Beel, a Ramsar site of Assam, India. Indian J. Appl. Res., 1(11): 947-950.

Dutta, S., Maity, S., Chanda, A., Akhand, A. and Hazra, S. 2012. Length-weight relationship of four commercially important marine fishes of Northern Bay of Bengal, West Bengal, India, J. Appl. Environ. Biol. Sci., 2(2): 52-58.

Froese, R. and Pauly, D. 2018. Fish Base. World Wide Web electronic publication. www.fishbase.org, Version $(10 / 2018)$.

Froese, R. 2006. Cube law, condition factor and weight-length relationship: History, meta-analysis and recommendations. J. Appl. Ichthyol., 22: 241-253.

Jayaram, K. C. 1999. The freshwater fishes of the Indian Region. Narendra Publishing House, New Delhi, 551 pp.

Khan, M. A., Khan, S. and Miyan, K. 2012. Studies on lengthweight and length-length relationships of four freshwater fishes collected from River Ganga. J. Fish. Aquat. Sci., 7: 481-484. http://dx.doi.org/10.3923/jfas.2012. 481.484.

Koushlesh, S. K., Sinha, A. and Kumari, K. 2018. Length-weight relationship and relative condition factor of five indigenous fish species from Torsa River, West Bengal, India. J. Appl. Ichthyol., https://doi.org/10.1111/jai.13518.

Kulbicki, M., Guillemot, N. and Amand, M. 2005. A general approach to length-weight relationships for New Caledonian Lagoon fishes. Cybium, 29: 235-252.

Le Cren, E. D. 1951. The length-weight relationships and seasonal cycle in gonad weight and condition in the perch (Perca fluviatilis). J. Anim. Ecol., 20: 201-219.

Natarajan, V. 1971. Biology and fishery of Labeo calbasu (Ham.) in Bhavanisagar Reservoir. Madras J. Fish., 6: 14-56.

Nath, K. D., Borah, S. and Yadav, A. K. 2017. Length-weight and length-length relationship of four native fish species from Barak River, Assam, India. J. Exp. Zool. India, 20: 977-979.

Pathak, S. C. 1975. Length-weight relationship, condition factor and food study of Labeo calbasu (Ham.) from Loni Reservoir (M.P.). J. Inland Fish. Soc. India, 8: 58-64.

Pethiyagoda, R. 1991. Freshwater fishes of Sri Lanka, The Wildlife Heritage Trust of Sri Lanka, Colombo, 362 pp.

Riedel, R., Caskey, L. M. and Hurlbert S. H. 2007. Lengthweight relations and growth rates of dominant fishes of the Salton Sea: implications for predation by fish eating birds. Lake Reserv. Manag., 23(5): 528-535, DOI: 10.1080/07438140709354036.

Sarkar, M., Das, S. K., Mondal, A. and Bhakta, D. 2017. Lengthweight relationship and relative condition factor of carps Labeo bata and Labeo rohita from Kulia Beel (wetland) of Nadia District of West Bengal. J. Entomol. Zool. Stud., 5(5): 1033-1036. DOI: 10.3923/jfas.2012. 
Singh, D. N., Murugesan, V. K. and Das, A. K. 2003. River Cauvery - Environment and Fishery, Bulletin No. 119. ICAR-Central Inland Fisheries Research Institute, Barrackpore, Kolkata, India, 28 pp.
Ujjania, N. C., Sharma, L. L. and Balai, V. K. 2013. Lengthweight relationship and condition factor of Indian major carp (Labeo rohita Ham., 1822) from Southern Rajasthan, India. Appl. Biol. Res., 15(2): 1-5. 